\title{
INDONESIAN WEAVING CULTURE INNOVATION: A STUDY OF COLLABORATION AND INDIVIDUAL ACTORS
}

\author{
Sonny Rustiadi dan Nina Arina \\ 1School of Business and Management Institut Teknologi Bandung, Jl. Ganesha No.10, Kota \\ Bandung, Jawa Barat 40132, Indonesia. \\ Email: sonny_r@sbm-itb.ac.id/ nina.arina@sbm-itb.ac.id
}

\begin{abstract}
The contribution of Indonesia's economic creative subsector to total Gross Domestic Product (GDP) increased for about 7.38 percent in 2015. To improve this performance, Indonesian Agency for Creative Economy conducting product innovation and skill development through the capacity building plan. The purpose of this article for publication is to see the approaches, to analyze the responsibility of each stakeholder involved, and to know the operation in innovating conduct by Noesa (Indonesian local brand) and Watubo (rural artisan) in the form of collaboration and also Lepo Lorun in the form of individual actors. This article of publication used exploratory analysis, that consist of short ethnography and deep interview. The analysis begins with a description of the products and services offered and continue with $3 \mathrm{C}$ model and 'The Condition' model from Drucker (1993). The analysis of this article for publication concluded that there are different ways of innovating through collaboration with different individual stakeholders. Each party has its own role in the community and targets its own objective in accordance with the provisions established. However, what interesting is that these two types of capacity building have the same goal, namely to re-learn weaving through different approaches. The results of this study are also expected to be a consideration to find out an effective and efficient way to promote Indonesian waving culture.
\end{abstract}

Keywords: creative economy, innovation, ikat weaving, collaboration, local brand, rural artisan

\section{Abstrak}

Kontribusi subsektor ekonomi kreatif Indonesia meningkat menjadi total Produk Domestik Bruto (PDB) sekitar 7,38 persen pada tahun 2015. Mendukung hal tersebut, Badan Ekonomi Kreatif Indonesia terus meningkatkan kinerja melakukan perencanaan pengembangan kapasitas dan dua di antaranya adalah melalui inovasi produk dan meningkatkan keterampilan. Tujuan dari penelitian ini adalah untuk melihat pendekatan, pemangku kepentingan, dan operasi dalam melakukan inovasi oleh Noesa (merek lokal Indonesia) dan Watubo (pengrajin pedesaan) dalam bentuk kolaborasi dan 
juga Lepo Lorun dalam bentuk aktor individu. Metode yang digunakan dalam penelitian ini adalah analisis eksploratif melalui wawancara dan etnografi singkat. Analisis dimulai dengan deskripsi produk dan layanan yang ditawarkan menggunakan marketing mix. Kemudian dilanjutkan dengan menganalisa Model 3C dan teori 'The condition' oleh Drucker (1993). Hasil dari penelitian ini adalah bahwa terdapat berbagai cara berinovasi melalui kolaborasi dan sebagai aktor individu. Setiap pihak memiliki perannya sendiri dalam masyarakat dan menargetkan targetnya sendiri sesuai dengan ketentuan yang ditetapkan. Namun, yang perlu diketahui adalah bahwa kedua jenis pembangunan kapasitas ini memiliki tujuan yang sama, yaitu untuk belajar kembali menenun melalui pendekatan yang berbeda. Hasil penelitian ini juga diharapkan dapat menjadi pertimbangan untuk mengetahui cara yang efektif dan efisien untuk mempromosikan tenun Indonesia.

Katakunci: ekonomi kreatif, inovasi, tenun ikat, kolaborasi, brand lokal, pengrajin pedesaan

\section{INTRODUCTION}

Each original idea has a uniqueness of their own. Today, original and creative thinking can be a lucrative source of income for the people that can exploit and commercialize their ideas. This is further known as the creative economy, a term first coined by John Howkins. According to Howkins (2001), creative economy "is the transaction of creative products that have an economic good or service that results from creativity and has economic value".

The influence of creative economy in Indonesian economic discourse has begun to draw considerable interest. This is reflected by the growing significance of the creative economy. In 2014, Indonesian creative economy economic contribution reached 784.82 Trillion Rupiah and increased to 852.24 Trillion Rupiah in the following year, a growth rate of 4.38 percent. The growth is dominated by three creative economy sub-sectors of culinary, fashion, and craft (Bekraf, 2017). In addition, these three creative sectors also increasing in importance for their contribution to the total GDP amounting to 7.38 percent of the total GDP in 2015.

Within that period, the craft subsector became the third largest subsector of Indonesia's creative economy in contribution to the GDP with a percentage of 15.70 percent $^{1}$. In addition to occupying the third position in terms of subsector contributions, the craft is also having a significant contribution to exports. According to statistical data and survey of creative economy in 2017, 37 percent of the creative economy exports are gain from the craft subsector.

With the high contribution of the craft subsector, it cannot be denied that craft means one of the most

1 The first position was occupied by culinary with a percentage of 41.69 percent and the second position occupied by fashion with a percentage of 18.15 percent (Bekraf, 2017). 
promising sources of income for the stakeholders. So far, creative economy exports (including craft) are still dominated by the western part of Indonesia (Bekraf, 2017). Whereas in eastern Indonesia there is a variety of crafts that are no less interesting. But in marketing and innovation processes still need to be developed. According to listing from Global Creativity Index (GCI) ${ }^{2}$, Indonesia was placed $115^{\text {th }}$ out of 139 countries with GCI of 0.202 in 2015. Within the GCI list, Indonesia's position is still lower compared to neighboring country of Malaysia, with GCI value of 0.455 and occupies 63rd position (Florida, Mellander, \& King, 2015). This fact indicates that Indonesia need to better develop its creative potential. This article for publication investigates case study for ikat weaving collaboration and cocreation practices in Flores Indonesia analyzed from product innovation perspective and skill development perspective.

The purpose of this study is to see the approaches, map stakeholders, and the operationability of creative processes and skill development in creating creative products and services in both case studies and compared them for similarities and differences.

\section{METHOD}

The method employed is exploratory analysis. The exploratory analysis divided into two focuses of capacity building. The first is product

${ }^{2} \mathrm{GCI}$ is a broad-based measure for further economic growth and sustainable prosperity based on The 3Ts model of Talent, Technology, and Tolerance (Florida et al., 2015). innovation collaboration practices between Indonesian fashion brand based in Jakarta called Noesa with rural artisan group in Maumere Flores called Watubo. The second case study is skills development of a group of rural artisan in Maumere Flores called Lepo Lorun. The analysis begins with a description of the products and services of each group. Then the analysis proceeds with investigating the collaboration process by applying 3C Model and 'The Condition' theory by Drucker (1993) framework. Short ethnography is undertaken to understand the process and gather data for this article for publication.

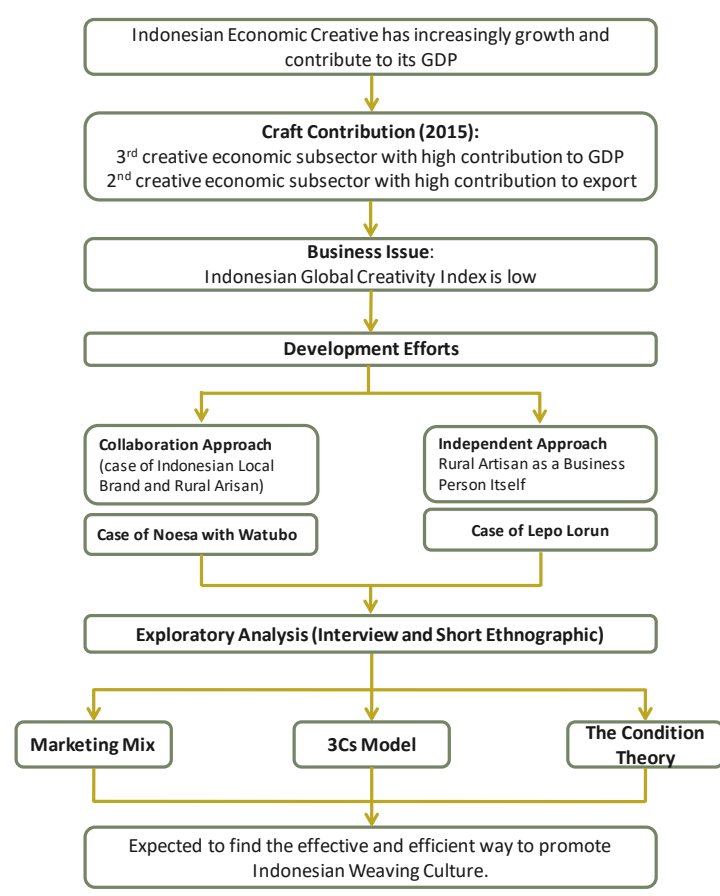

Figure 1. Framework

\section{Research Objects}

\subsection{Partnership of Noesa and Watubo}

As a background, activities of Noesa with Watubo and Lepo Lorun for their products and services 
offerings is analyzed. Noesa is a brand that specializes in fashion accessories. The young people who loves culture are their main target market. So, the company is challenges in developing products that is fashionable yet functional for their market. Noesa cocreates their product with Watubo, a group of weavers in Flores. There are division of labor that distinguishes the work portion of Noesa that depends on their respective expertise. Noesa have responsibility in managing finances, providing facilities, making project schedule based on weather season (usually start in April), and promoting outside of Flores. Meanwhile, Watubo have responsibility in weaving, operating the workshop, and promoting in Flores. For them, this work division did not have to be made by organization structure as long as the work divides is clear.

For about three months, Noesa performed research and development from creating patterns, designs, and colors scheme for their products. After it is decided, Noesa then communicate with it with Watubo. In addition to remote communication, There is also a routine visit time (once a week) by Noesa's team to Watublapi village so they could interact directly with the weavers. After creating patterns, designs, and colors scheme by Noesa with approval from Watubo, then Watubo began to weave the yarn to be made as raw material for Noesa to produce as final products. Usually, Watubo need (approximately) 1 month to produce (approximately) 5 to 6 pieces of woven fabric individually. The fabric sized around 80 centimeters by 3 centimeters.

Historically, the first product that they made was a camera strap. It was launched when mirrorless cameras and prosumer cameras were gaining popularity (perfect timing). After that camera strap had launched, Noesa continue to develop other products including passport holder, hat, bag, necklaces, and bracelets. Best seller product to date is still the camera strap. Its the unique shape and differences that being a characteristic to this camera strap. It could be a camera strap that resembles as a scarf, so people can easily use it as accessory/ scarf to the plain clothes and wear the camera strap as the camera strap. Further, by developing rare color that cater more to the youth market, it actually becomes Noesa's Unique Selling Point (USP). Other brands that use natural dyes did not have color choices as much as Noesa. Noesa and Watubo also offer workshops and homestays (under product name of Orinila) in which people can learn more about ikat weaving and natural dye, experiencing it directly in Watublapi Village in Flores (home of Watubo) and in Jakarta (home base of Noesa). The goods and services developed by Noesa and Watubo tend to start from things that can be used daily, so that the market start to love weaving products, be it little by little. "Pelanpelan mencintai tenun." - (Rosvita ${ }^{3}$, Personal Interview, 1/05/2019)

3 Mama Rosvita is considered the tribe leader of Watubo, and is one of the main respondents of this research. 
Noesa do the promotion both via online (social media, website) and via offline (events mostly in Jakarta) while Watubo promotes primarily offline in Flores. In online channel, their product and service can be accessed via various social media handle including Facebook, Twitter, Youtube, Pinterest, Instagram, Marketplace, and Noesa Website. For digital channel, Noesa work together with several consignment stores in Bali and Jakarta. There are many region in Indonesia that is famous for traditional textile as a signature of culture, however Flores is one of the primary destination for ikat weaving (Buckley, 2012). To show this, Noesa develop a journal session on their website called journal.noesa.com. From this journal, people can also learn about Indonesian heritage ikat weaving; see the process of textile making; and know why it becomes one of Indonesian cultural identities. Orinila (the homestay service), located in Sikka Regency, Watublapi, Maumere, also provided for visitors. From "Bincang Noesa" article with Peter Ten Hoopen, it is in line with Noesa's mission that:

"For disappearing cultures, documentation is the heart of conservation". (Hoopen, 2018)

\subsection{Lepo Lorun}

Different from collaboration of Noesa with Watubo in which each party have their respective role and duty in creating and developing products, Lepo Lorun is an independent group of weavers that function both as designer and weaver of their own product. Within the limit in which Lepo Lorun consist mostly of mothers whom started to weave since childhood, their skills are more about making weaving rather than creating and developing contemporary products and designs. The products they sell mainly are sarongs with limited product variations. Other products that they produce includes clothes, scarves, belts, small bags, bracelets and headbands. Lepo Lorun also offer services such as traditional clothing rental and homestays. They do not, however, offer open trips to general public. Their service is more accustomed by customers request.

"Ya biasalah hanya meneruskan
kegiatan tradisi yang sudah biasa.
Terus perempuan-perempuan Sikka
yang udah dari sananya lahir
dipakemkan. Berarti dia harus bisa
tenun. Peruntukannya untuk balasan
mas kawin. Jadi bukan kita tenun untuk
mata pencaharian. Jual tenun beli beras.
Jual tenun bayar listrik, air, atau untuk
senang-senang. Tapi memang tenun
fungsi peruntukan utamanya untuk
memenuhi kebutuhan tradisi dan
pakaian." - (Alfonsa Horeng, Personal
Interview,29/04/2019)

Lepo Lorun does not have its own website for selling and promotion. But some websites have also promoted Lepo Lorun like indonesiakaya.com. In addition, Big Story Small Town ${ }^{4}$ also made a documentary film for Lepo Lorun entitled "Au Lorun". For about 75

${ }^{4}$ Big Stories, Small Towns is an ongoing, online and participatory documentary series that explores community life in small towns. The project's producer is Big Stories Co. and principal funder is Screen Australia. Filmmakers-inresidence live in a small town for several months, working with locals to capture the stories of the community. 
minutes, the film interviewed 13 Lepo Lorun weavers filmed in their homes. Whereas offline, Lepo Lorun (represented by one of the elder in the tribe, Alfonsa Horeng) usually accepts invitations abroad through embassies and universities and school for example through Australia Leadership Award Program and as a case study example at the last 2018 World Conference on Creative Economy.

"...Kemudian diundang juga "kamu ke Sidney, kasih lecture". Jadi kebetulan ada foto-foto disini. Jadi setiap temanteman bule mau ada apa-apa di e-mail, saya presentasi ini ini. Jadi saya presentasi saja. Giliran ditanya ya seputar apa yang saya bawa ini. Jadi begitu tau mereka undang. Kami kan senang aktivitas-aktivitas yang seperti itu." (Alfonsa Horeng, Personal Interview,30/04/2019)

The process flowchart of Lepo Lorun is shorter than Noesa with Watubo. Bookings, visits, and events/ exhibitions invitation is received by Lepo Lorun directly. After order is agreed, the group leader, Alfonsa Horeng, began delegating tasks to the weavers in the studio according to their respective abilities. The basic material used to fulfill the order is provided so that the weavers only duty is to work immediately. Work on fabric usually take 2 to 3 months. If there are no orders, the weavers will put their finished products in the community studio, so that it may be bought by tourist who visits their village. The weaving process is generally the same as in Watubo, which starts from rolling the yarn, binding the yarn to make motifs, coloring, and weaving. After the final product finish, Lepo Lorun does product marketing either online or offline (mostly offline through the studio and exhibition).

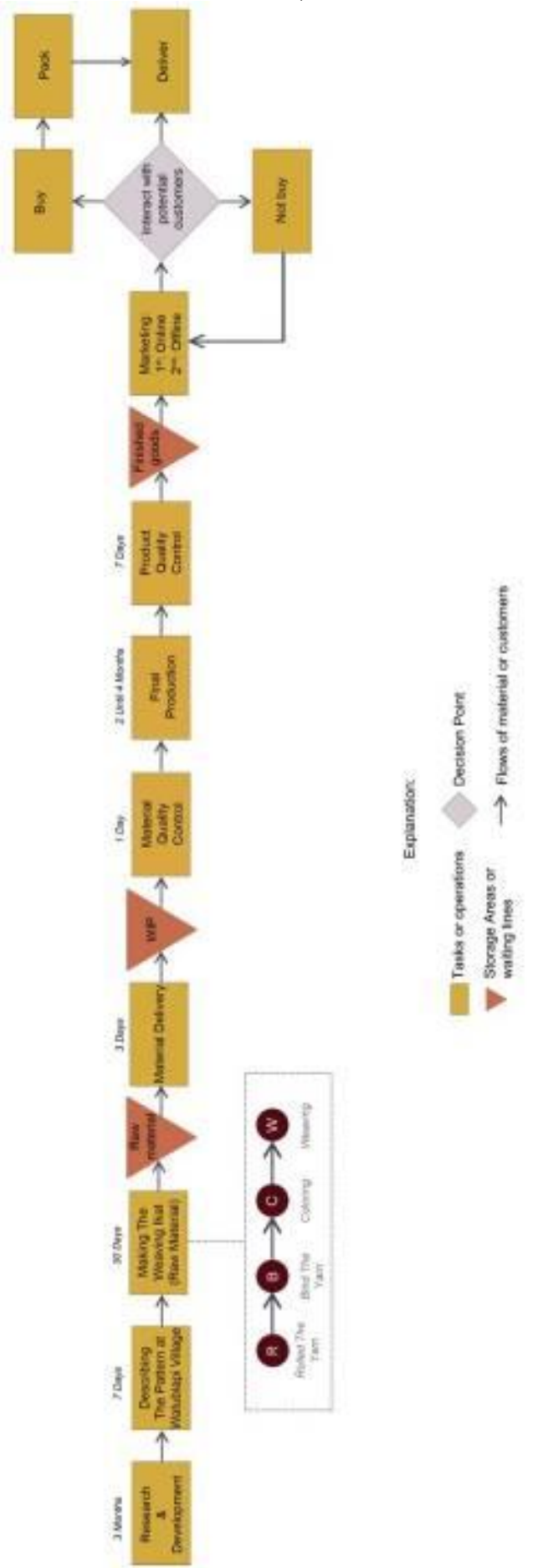

Figure 2. Flow Chart of Noesa and Watubo 


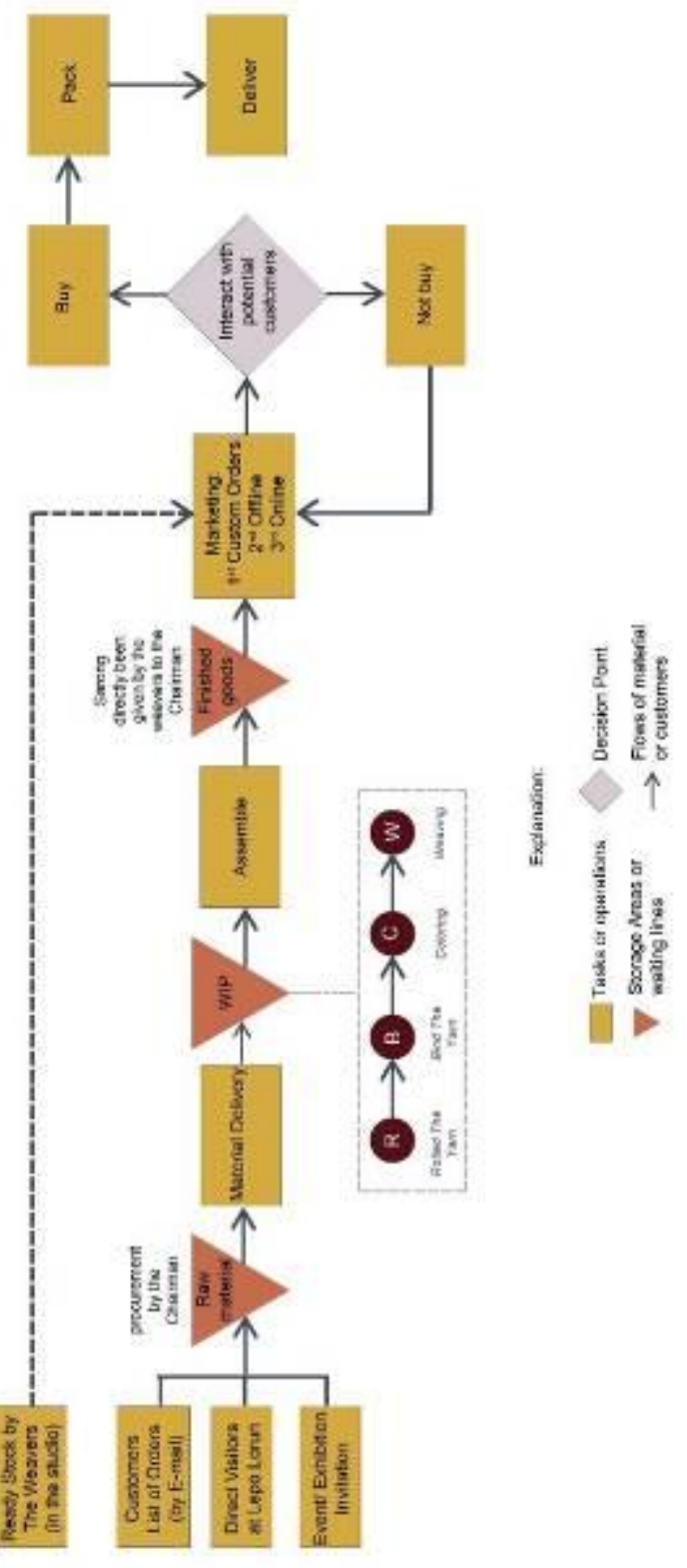

Figure 3. Flow Chart of Lepo Lorun

\section{RESULTS AND DISCUSSION}

\subsection{C Model (Cooperation - Coordination - Communication)}

This section analyzes various aspects in doing collaboration to both of our case studies by applying the $3 \mathrm{C}$ model consisting of Cooperation, Coordination, and Communication coined by (Ellis et al., 1991). Communication investigate the exchanges of word, message, and information is used as a tool of negotiation and decision making by related parties. Coordination analyze the interactions of resources, people, and activities or tasks. Coordination is carried out to minimize the risk of conflict from happening and organize the activities by encouraging communication and fostering teamwork. Cooperation examine the production process. Cooperation is reflected in terms of work space (job allocation) and the execution of each parties' job to arrive at common goal(s) (cooperation objective) (Fuks et al., 2007). This article for publication will identify the framework using a system of flow chart that follow the operational, the task coordination, and the duration of the cooperation process.

\subsubsection{Communication}

In the case of Noesa and Watubo, majority of communication are done using WhatsApp and telephone to communicate information such as the fabrics pattern and design to be made. There are five design graduates in Noesa's design team. This has enabled the company to operate efficiently. The fabric pattern designed by Noesa always take into account the ability of Watubo weavers in making yhe textile. Upon finishing the design, Noesa then will inform Watubo weavers to review the feasibility of actually making the pattern. Then it would be decided whether the design would be proceed into weaving 
process, or need further adjustment from Noesa design team. The communication also done to set the quality control of fabric production located in Watublapi Village. The quality control process for Noesa and Watubo is mainly based on trust between the parties. From the beginning of the process, Noesa has communicate their standpoint in good quality product, so the Watubo artisan has understood and attune the weaving process accordingly.

Communication was also important for Watubo to Noesa when facing crisis management or solving a problem (for example machineries broken down or homestays facilities not up to standard). One case example happened in early 2018, when rainy season comes and home stay building (that made from bamboo) was significantly damage. At that time, the visit for tourist to the workshop in Watublapi Village ceased to be scheduled from January to April while reparation was conducted.

Communication and trust between the Watubo and Noesa are critical in their relationship and cooperation, especially if problems happened. Through communication, coordination was formed with the objective to ensure efficiency and effectiveness in managing resources, people, and purposive tasks to achieve. Division of labor is done accordingly with the expertise of each party. Although, geographically, there is a difference between Jakarta where the main commerce activities and Flores where the fabrics are made, this not been a constraint to all parties.
Mama Rosvita, the Watubo elder, said that:

"Sebenarnya tidak ada kendala
sama sekali, karena intinya cuma
komunikasi. Kita sering berkomuikasi.
Dan setiap ada kendala apa-apa dari
pihak Watubo selalu ditanyakan. Dan
sampai saat ini memang ada beberapa
kesalahan sedikit tapi Noesa memahami
itu dan seiring berjalannya waktu,
karena kan melakukan hal yang baru
butuh waktu butuh proses, dan setelah
itu sudah mulai berjalan dengan baik."
(Rosvita,
Interview,25/04/2018) Personal

In the second case studies, communication between Lepo Lorun members is done directly with face to face in their studio. If it is not in the studio, communication is done via sms for certain purposes. Alfonsa as chairman has the responsibility to communicate every activity requested by consumers to Lepo Lorun. If weavers in the studio find obstacles either personal or the ability to fulfill orders, they always communicate these limitations directly to Alfonsa Horeng.

"Kalau tamu datang mereka beli kami punya hasil tenun. Itu kan dapat uang toh. Itu kalau tidak ada yang beli, tapi kami butuh sekali itu kami bilang nona (Alfonsa). Nona (Alfonsa) tolong kami punya sarung ini kamu butuh uang karena kami punya anak-anak atau kami sakit. Pokoknya ada kebutuhan apa kami bilang nona (Alfonsa). Nona (Alfonsa) juga ambil kami punya sarung." (Antonia, Personal Interview, 30/04/2019)

But in some cases, when there are invitations (internationally and nationally), sometimes weavers in the studio did not know the purpose of 
Alfonsa Horeng's visit from the invitation.

"Tahun lalu-lalu biasanya ibu (Alfonsa) pergi sendiri. Kadang kalau ibu (Alfonsa) yang kunjungan pergi buat apa juga kami disini tidak tau." (Mariustina, Personal Interview, 30/04/2019)

\subsubsection{Coordination}

Coordination is aim to administer the activities or tasks to arrive at a particular objective. In the case of Noesa and Watubo, on the home stay services offered, the infrastructure in the village is limited. The village does not have expected luxury facilities by visitors. There is an access limitation due to water, electricity and phoned signal. Further Watubo artisans can only provide food which they usually cook every day. In terms of homestay services, Orinila at Watublapi Village enable the visitors to have genuine waving where the actual making of ikat weaving textile is done.

While in Lepo Lorun, they realizes that with a studio, weavers have a decent place to work, where they go to work every day. Lepo Lorun studio make an easy way for the weavers to coordinate. With the time to work starting at 8 am until 4-5 $\mathrm{pm}$, they can focus more on doing work. One of the weavers in Lepo Lorun also mentioned that the existence of a studio created a positive feeling in terms of exchanging ideas and giving input to one another.

"Kalau saya pribadinya saya senang tuh kan kami kerja dirumah tuh sendiri. Minta bantu anak-anak sibuk semua. Ada kalanya kita malah emosi dengan mereka. Kalau disini kita bantu-bantu semuanya.
Nah itu senang sekali. Kalau kita buat kesalahan miring sedikit itu ada teguranteguran dari teman jadi kami senang. Warna itu kau kasih harus tambah ini itu bagi saya senang masukan dari teman. Dengan saling membantu." - (Antonia, Personal Interview, 30/04/2019)

\subsubsection{Cooperation}

Noesa and Watubo cooperation happen in two separate cities, which are Jakarta and Maumere. Noesa have office in Cipete, Jakarta with tasks including design making, logistic, and online and offline marketing. The work does not require a large office and can be arranged by small team only. On the other hand, Watubo works in Watublapi Village, Maumere, Flores. Watubo has critical job in making ikat weaving textile. The equipment used to make the ikat weaving textile still a traditional equipment. In using the traditional equipment, the process creates the value of Indonesia's cultural heritage. The division of labor is organized to accomplish main goal of Noesa and Watubo, which is to offer goods and services for customer, both for its fashion product using waving textile and the homestay service.

Many collaborations carried out by Lepo Lorun with international parties are supported by the proficiency of Alfonsa in English every time there is a visit in the studio or when she attended the invitation internationally. The approach taken in building cooperation with international parties was considered quite good considering that she often received invitations abroad. With good cooperation, networking and exchanging contacts are felt to be the 
most important things during Alfonsa's journey. Through a strong network Alfonsa can maintain good relations for many years with several parties through e-mail, such as associations, folk art, consortia for natural dyeing, and others.

"Saya satu orang bisa weaving, bisa
presentasi, bisa kasih workshop weaving,
bisa kasih gaya tarian Flores yang bisa
diangkat, terus jelaskan untuk tourism
juga. Pelajaran-pelajaran tentang tenun
kita kasih. Isi kedutaan-kedutaan punya
acara. Biasanya ada Indonesian
Independence Day di Brazil di undang.
Atau di Sidney bantu-bantu data pemilu
isi. Jadi kita harus proaktif. Nanti mereka
kontak terus. Nah giliran dia sudah jadi
Dubes Brazil "oh pak dulu saya di Sidney
begini begini" terus nanti diundang ke
Brazil. Jadi tidak hanya satu negara tapi
berkelanjutan diundangnya. Di
Wahington acara textile and Politic, atau
kita ada asosiasi tekstil Amerika."
(Alfonsa Horeng, Personal
Interview,30/04/2019)

\subsection{The Condition Theory}

An exploratory method was implemented through interviews with Noesa (in Jakarta), Watubo (in Watublapi Village, East Nusa Tenggara), and Lepo Lorun (in Nitta, East Nusa Tenggara) continued with a short ethnography. Ethnography described as the domain within anthropology as a tool to understand how people live their lives (Anderson, 2009). There were several main themes used as a guide for this article for publication which was chosen to help address the research questions of this article for publication taken from Drucker, (Innovation and Entrepreneurship, 1993) which are: purposeful, innovative, simple, start small and aim at leadership (Drucker, 1993).

\subsubsection{Purposeful}

Relationship between Noesa and Watubo is defined as collaboration according to Stoner (2013) that two or more brands work together to make new product or service from a shared vision. Noesa has commitment to introduce ikat weaving to the new generations and millenials whereas Watubo has an aspiration to increase their product sales. The collaboration began with Noesa helping Watubo to market their home-made woven fabrics to customer outside of Flores, in particular to customers in Jakarta. Thus, the collaboration began with economic drive. The objective of the collaboration was also was set clear from the beginning, to re-educate the market with Indonesian cultural heritage of woven fabric. With this objective, the market education of ikat weaving has been consistently done through clear product description, events such as exhibitions and workshops, and homestay service. Not much different from the purpose of Noesa and Watubo, Lepo Lorun established as a means to continue the existing culture through the studio that accommodate women weavers in the surrounding area.

\subsubsection{Innovative (both Conceptual and Perceptual)}

From consumers, visitors, and guests' side, the product value is not optimal yet delivered to them. From the interviews, it found the consumers, visitors, and guests that still think weaving ikat and batik are 
the same thing. In terms of Orinila, there are still many guests and visitors that feel less satisfied with the offered facilities. Many guests and visitors whom follow the open trip have high expectations. Thus, more information offered from Noesa and Watubo are important for them, so that expectations and offers could meet. Besides that, the number of stories summarized in 1 type of cloth has not been conveyed well to its consumers. The story is only told directly in an activity/ exhibition without being written so that it does not stick well to its customers. Although the variety of products and services offered by Lepo Lorun is less than Noesa and Watubo, what they have offered can be conveyed conceptually and perceptually. Consumers want the things offered by Lepo Lorun. And perceptually, Lepo Lorun is able to convey the value of its goods to consumers. However, because many of their customers are internationally, the delivery of product values can be an obstacle if the ability to explain in English only belongs to the chairman, so that it can create limitations for the weavers in the studio in this case.

\subsubsection{Be Simple and Focused to be Effective}

Between Noesa and Watubo, decision-making process is mainly carry out by Noesa. However, a number of elements (for example: design, pattern, quality control, and technical details are need to be attuned to the level of skill of the Watubo weavers and needs to be communicated accordingly. What important between Noesa and Watubo is the trust and communication on one to another. From the Lepo Lorun side, all decisions were made by the chairman. The decision is related to receipt of orders, visits, and exhibition invitations. Chairman of Lepo Lorun take this decision considering the capability and capacity of the weavers in the studio.

\subsubsection{Effective Innovations Start Small}

Noesa and Watubo began their venture with offering product that is quite small and not complicated, i.e. simple woven fabric textile without any further process. Noesa and Watubo used the fabrics to create fashion accessories for the first product launch and became the best seller up until today which is the camera strap. This is quite precise because both parties wanted to infuse a functional yet fashionable quality to their product. Further, in terms of services offered, Noesa and Watubo also began from simple offering of a simple day trip package. Now, the open trip packages offered plenty of range day (from one day to eleven days), with each have their respective specifications in keeping with what is required and desired by the guests. In addition, the team that runs the operations to produce these products and services is a small number of teams. Noesa have 3 people and only in 2019 increased to 5 people while Watubo have of 25 members from one big family. In contrast to Noesa and Watubo, Lepo Lorun always continued the existing types of 
products and services. It is very rare for Lepo Lorun to make a new type of product because they have the specifications of the sarong as something sold. If there are modifications to the motif, the motif is also taken from an old motif which is then redeveloped. The beginning of the founding of Lepo Lorun began with 13 weavers collected in the studio and now it has developed in several branches.

\subsubsection{Aim at Leadership}

What Noesa and Watubo is offering to the market has big potential commercially because there are not yet many similar competitors. As Noesa is positioned as a brand of fashion accessories in Indonesia that uses natural dyes for accessories, because most of brands uses natural dying product for apparel products. Noesa has unique proposition as not all brands create the same products because they are not seeing the opportunities seen by Noesa. Further, no other brand in the market features ikat on fashion accessories. For the home stay service, there are not many other companies or agents that facilitate an open trip. Many of the open trip are intended for nature trip, while Noesa and Watubo offer cultural heritage trip, particularly ikat weaving. One of the communities that facilitate similar services is Lepo Lorun that established earlier than Watubo (established in 2002). Lepo Lorun also has the potential to be a market leader considering their propositions. Independently, Lepo Lorun can penetrate the international arena. Through network and connections, the skills of the elders in foreign language, and international invitations by maintaining relationships that have been established are the key that enables Lepo Lorun independently to continue to innovate in accordance with the current market development.

\section{CONCLUSION}

Through the elaboration of the result and discussion section, it was found several differences in capacity building built by Noesa with Watubo and Lepo Lorun as follows.

Table 1. Capacity Building: Noesa with Watubo

\begin{tabular}{l} 
Capacity Building \\
\hline $\begin{array}{l}\text { PRODUCT INNOVATION: Collaboration } \\
\text { with Indonesian Local Brand } \\
\text { (Case of Noesa with Watubo) }\end{array}$ \\
\hline \multicolumn{1}{c}{ Background: Marketing Mix } \\
\hline - \\
Motives developed: contemporary and \\
traditional \\
- There is no rental of traditional clothes \\
More extensive distribution channels \\
managed by Noesa \\
The process of flow chart is longer \\
considering there are two parties \\
involved \\
\hline \multicolumn{1}{c}{ Investigation: 3C Model } \\
\hline Although working in two different \\
places, communication is not seen as an \\
obstacle. \\
Division of work based on the skills of 2 \\
parties. \\
Collaboration that appears is more \\
managed and emerges from Noesa.
\end{tabular}


4. Start from small team, small variance of product;

5. Together have the possibility to be market leader.

Table 2. Capacity Building: Lepo Lorun

\begin{tabular}{|c|c|}
\hline & \\
\hline & $\begin{array}{r}\text { Artisan a } \\
\text { (Ca }\end{array}$ \\
\hline & Back \\
\hline & $\begin{array}{l}\text { Motives developed: traditional } \\
\text { There is no special workshop and of } \\
\text { trip } \\
\text { More intimate distribution channels } \\
\text { The flowchart process is shorter }\end{array}$ \\
\hline & \\
\hline & $\begin{array}{l}\text { In the case of invitations that are } \\
\text { sometimes only the chairman knows; } \\
\text { Division of work based on the weaver's } \\
\text { ability of orders received by the } \\
\text { chairman; } \\
\text { More international cooperation through } \\
\text { an invitation for a visit to the chairman. }\end{array}$ \\
\hline & $\begin{array}{r}\text { Innovation: } \\
\text { I }\end{array}$ \\
\hline & \\
\hline & (English) limitation by the \\
\hline & $\begin{array}{l}\text { Decision making by the chairman with } \\
\text { weavers' capability and capacity to } \\
\text { consider; }\end{array}$ \\
\hline & $\begin{array}{l}\text { from the small team, } 1 \text { focused } \\
\text { uct (sarong); }\end{array}$ \\
\hline & $\begin{array}{l}\text { ve the possibility to be } \\
\text { bally). }\end{array}$ \\
\hline
\end{tabular}

\section{REFERENCES}

Anderson, K. 2009. Ethnographic Research: A Key to Strategy. Retrieved February 13, 2018, from https://hbr.org/2009/03/ethnographic -research-a-key-to-strategy.

Bekraf. 2017. Data Statistik dan Hasil Survei Ekonomi Kreatif.
Buckley, C. D. 2012. Investigating Cultural Evolution Using Phylogenetic Analysis: The Origins and Descent of the Southeast Asian Tradition of Warp Ikat Weaving. PLOS ONE, 7(12).https:// doi.org/10.1371/jo urnal.pone.0052064.

Drucker, P. F. 1993. Innovation and Entrepreneurship (First Pere). New York: HarperCollins Publisher.

Florida, R., Mellander, C., \& King, K. 2015. The Global Creativity Index 2015, 68. Retrieved from http://martinprosperity.org/media/Gl obal-Creativity-Index-2015.pdf.

Fuks, H., Raposo, A., Gerosa, M. A., Pimental, Pimental, Mariano, \& Mariano. 2007. The 3C Collaboration Model. Encyclopedia of E-Collaboration, 637-644. https:/ / doi.org/10.4018/978-159904-000-4.ch097.

Kotler, P., \& Keller, K. L. 2009. Marketing Management. Organization, 22. https:// doi.org/10.1080/089117 60903022556.

Howkins, J. 2001. The Creative Economy: How People Make Money from Ideas. London: Penguin Books.

Merina, N. 2018. UMR Jakarta 2018 Terbaru, Berapa Kenaikan Gaji UMR dari Tahun ke Tahun? Retrieved April 11, 2018, from http://goukm.id/umr-dki-jakarta2018/.

Stoner, J. L. 2013. Let's Stop Confusing Cooperation and Teamwork with Collaboration. 
Retrieved February 17, 2018,

from

https://seapointcenter.com/cooperati

on-teamwork-and-collaboration/. 
APPENDIX

Appendix 1: Photo Products and Services Offered by Noesa-Watubo
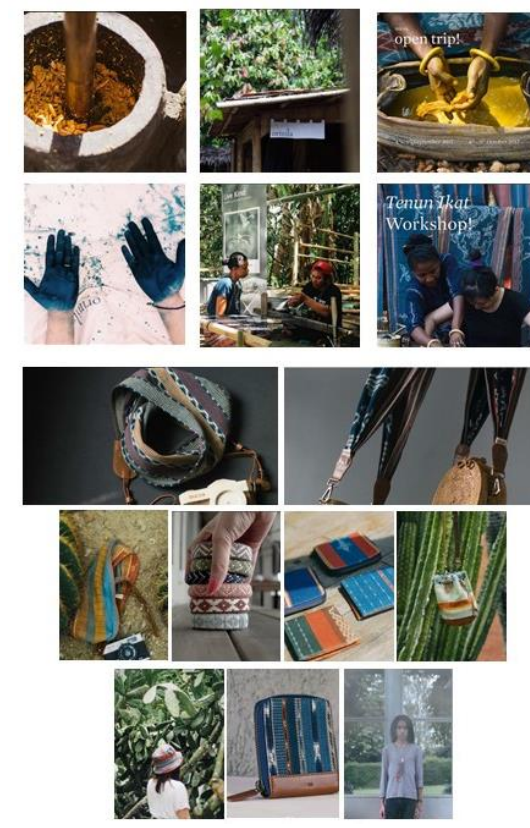

Appendix 2: Photo Products and Services Offered by Lepo Lorun
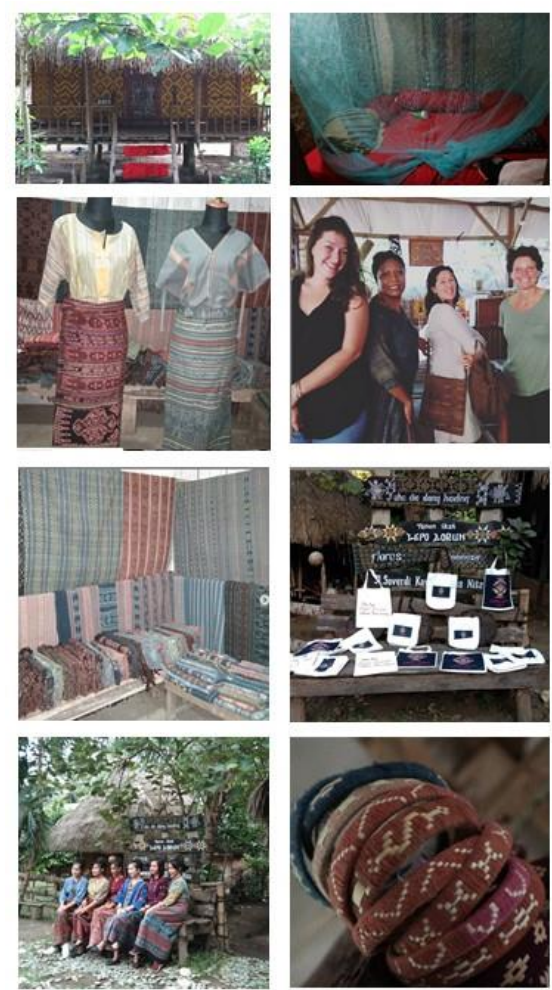

Appendix 3: Products and Services differentiation Offered by Noesa-Watubo and Lepo Lorun

\begin{tabular}{|c|c|}
\hline $\begin{array}{l}\text { Noesa with } \\
\text { Watubo }\end{array}$ & Lepo Lorun \\
\hline \multicolumn{2}{|l|}{ Goods: } \\
\hline $\begin{array}{l}\text { Categorized: } \\
\text { 1. Apparels } \\
\text { 2. Bags and Wallets } \\
\text { 3. Value Set } \\
\text { 4. Strap Camera } \\
\text { 5. Textile } \\
\text { 6. Hats belt, } \\
\text { 7. Accessories: cable } \\
\text { wrap, bangle, bandana } \\
\text { bangl, }\end{array}$ & $\begin{array}{l}\text { 1. Sarung } \\
\text { 2. Apparel } \\
\text { 3. Selendang } \\
\text { 4. Belt } \\
\text { 5. Bags } \\
\text { 6. Bangle } \\
\text { 7. Bandana }\end{array}$ \\
\hline \multicolumn{2}{|l|}{ Services: } \\
\hline $\begin{array}{l}\text { 1. Open Trip } \\
\text { 2. Home Stay }\end{array}$ & $\begin{array}{l}\text { 1. Maumere } \\
\text { traditional } \\
\text { clothes rental }\end{array}$ \\
\hline 3. Workshop & $\begin{array}{l}\text { 2. Home Stay } \\
{ }^{*} \text { No open trip }\end{array}$ \\
\hline $\begin{array}{l}\text { *No Maumere } \\
\text { traditional clothes } \\
\text { rental }\end{array}$ & $\begin{array}{l}\text { (based on } \\
\text { visited and } \\
\text { customers } \\
\text { needs) } \\
\text { *No workshop }\end{array}$ \\
\hline
\end{tabular}

